\title{
Foreign law in higher courts practice. The key characteristics of Georgian private international law
}

\author{
PhD. student Tamar MSKHVILIDZE
}

\begin{abstract}
This paper aims to investigate the application of foreign law in higher courts practice. The process of determining a foreign law raises practical difficulties, as a judge must apply not just foreign law acts, but also the case law and interpretation with which it is applied in another State. In private international law process the effectiveness of the application of foreign law depends on how correctly and delicately can the higher courts review decisions made by the first instances. In some countries, higher courts have the power to control the correct application or non-application of foreign law by judges, but in some cases, such courts lack this ability. In spite of the development of comparative jurisprudence and modern information technologies, none of the countries' judge can have a claim on exact knowing of relevant standards of the law of foreign countries. Consequently, the danger of making a mistake is more greater when it comes to interpreting and applying foreign law. Thus, it cannot be expected that the higher court should be able to review interpretation of foreign law acts applied by the lower courts and to provide that this interpretation is relevant to that which the practice of the foreign country would adopt on the same question. There is an opinion that the higher courts should refrain from control the wrong application of foreign law in order to guard their own authority, as there is a high risk of misinterpretation of a foreign rule. The different aspects of this problem will be examined in this article.
\end{abstract}

Keywords: private international law rules, treatment of foreign law, foreign substantive law, interpretation, misinterpretation, higher courts, lower courts, revision, cassation.

JEL Classification: K15, K39, K41.

DOI: $10.24818 / \mathrm{TBJ} / 2021 / 11 / \mathrm{SP} / 08$

\section{Introduction}

In the context of globalization, the transnational movement of people, services, goods and information is becoming even stronger. As a result, we get more intensive private international law relations in which not only large companies participate with their business transactions, but also ordinary people with a variety of day-to-day consumer, contract, matrimonial, inheritance, etc. relationships. ${ }^{2}$ This

${ }^{1}$ Tamar Mskhvilidze - scientist at Scientific Research Institute of Law of European University, Tbilisi; $\mathrm{PhD}$. Student at East European University, Republic of Georgia, tamarmskhvilidze@yahoo.com.

2 "Global interdependence of economies, societies and cultures, and regional integration increasingly question the traditional model of life and business being confined within the parameters of a single legal system. Personal and family or commercial situations connected with more than one country, and with more than one legal system, are now commonplace." Hans van Loon, Secretary General, Hague Conference on Private International Law, Access to Foreign Law in Civil and Commercial 
trend has naturally raised the application of foreign law in court practice. The main achievement of private international law is that, with help of private international law rules, States were able to overcome "legal nationalism" and abandon a closed, national legal system.

Why does one state apply the law of another at all? Basically, answer is that this is comity of nations. Foreign law is applied for being nice to other states. This attitude is grounded in the mutual interest of the states in having commercial and other contacts with each other. ${ }^{3}$ But is the relationship with other states really the reason for which we apply its law? There are certainly areas where concerns for bilateral relations and cooperation with other states influence the choice-of-law process. Certainly, we are not bound to apply another state's law. We do it for the sake of good relations with the other country. ${ }^{4}$

Under the traditional method to solve conflicts, the judge has to apply the law of the state to which the legal relationship belongs, in which it has its "seat". For every legal relationship there is a state which is competent. Private disputes are attributed to the jurisdiction of a state. The task of conflict is to "discover" the right state. ${ }^{5}$ While international legal harmonization can remove differences between national laws, and while the enactment of mandatory rules of the forum can obviate the need to prove foreign law at all, the reality is that foreign law is often applicable and often differs markedly from its local counterpart. ${ }^{6}$ The proper functioning of private international law in a domestic system is based on the appropriate application of law. In fact, a national court's adjudication of a foreign law claim can provide stability and fairness. ${ }^{7}$ Moreover, adjudication of substantive foreign law claims in domestic courts is possible without infringing the interests of another sovereign. Also, the resolution of a foreign law claims in a national courts is generally consistent with comity and amicable commercial relations among nations. ${ }^{8}$

When the court hears a case involving a foreign element, private international law rules will sometimes indicate that the applicable law is to be found

\footnotetext{
Matters, European Commission, (Brussels 17.04.2012), p. 3. One American author stated: "International litigation is an inevitable consequence of technological changes that have made the world a smaller place. American clients have accidents and disputes wherever they go, and the airplane allows them to go anywhere. When those incidents take place in foreign countries, the resulting litigation is complicated by the clash of two systems of law and procedure." Thomas F. Bridgman, Proof of Foreign Law and Facts, 45 Journal of Air Law and Commerce, 1980, p. 845. In one of the cases, the US Supreme Court made an interesting statement: „We cannot have trade and commerce in world markets and international waters exclusively on our terms, governed by our laws, and resolved in our courts." Lewis F. Powell Jr. Archives, Scherk v. Alberto-Culver Co. Supreme Court Case Files Collection, Box 18. Powell Papers, Washington \& Lee University School of Law, Virginia, 1973, p. 11.

${ }^{3}$ Matthias Lehmann, From Conflict of Laws to Global Justice, Columbia University, 2011, p. 27.

${ }^{4}$ Ibid, p. 28.

${ }^{5}$ Ibid, p. 33.

${ }^{6}$ James McComish, Pleading and proving foreign law in Australia, Melbourne University Law Review, Volume 31(2), 2007, p. 401.

${ }^{7}$ Matthew J. Wilson, Demystifying the determination of foreign law in U.S. courts: opening the door to a greater global understanding, The wake forest law review, 2012, p. 3.

${ }^{8}$ Ibid.
} 
in a foreign legal system, and not in the law of forum. When private international law rule refers the application of a foreign law rule to a particular legal relationship, then the court must apply that rule. How, is the content of that foreign law to be determined? This is a central question of private international law: without knowledge of the content of foreign law, the very concept of a true conflict of law becomes meaningless. ${ }^{9}$ The process of applying foreign law develops unfavorably because of the number of difficulties that accompany with ascertainment of its content. ${ }^{10}$ First of all, the application of the rule of another state in itself creates additional inconvenience, questioning the judge's ability to understand it correctly, because the legal culture, principles and customs on which this rule is based are unknown. This is not surprising - in his/her national law the judge is focused as an experienced lawyer, while applying foreign law as a beginner.

The problem that courts confront in attempting to apply foreign law is exceedingly difficult. Courts must begin to interpret foreign laws in light of relevant cultural, geographical and, most important, political factors. ${ }^{11}$ Those which arise before courts of first instance are of a general character. They concern the question whether foreign law is applied ex officio or upon application by the parties, what are the methods of proof and how it is to be interpreted. When the question is put whether the problems arising out of the question of foreign law extend equally to the sphere of the higher courts, the answer must be more diversified, in fact it depends primarily upon the judicial organization of the courts of the state. ${ }^{12}$ So, the question arises to what extent the failure to apply foreign substantive law or the wrong application of the foreign rules, applicable according to the rules of the private international laws, may form the basis of an application to quash the decision (cassation) or to modify it (revision) on a point of law.

\footnotetext{
9 James McComish, op. cit., 2007, p. 401.

${ }^{10}$ The commonly articulated explanation for the inability of courts to "reach" foreign law is the practical difficulty encountered in efforts to research and understand a foreign legal system. Several factors language difficulties, variant legal systems, and varying methods of practice and procedure exacerbate the problem of finding and interpreting foreign law. As one writer has stated: „Generally speaking the court has not the same certain and complete knowledge of foreign law as it possesses of the lex fori. This insufficient knowledge of foreign law, which is the natural consequence of the training of the judges in the law of their own country, affects decisively the circumstances in which the problem [of foreign law] arises." Alexander Gregory S., The Application and Avoidance of Foreign Law in the Law of Conflicts: Variations on a Theme of Alexander Nekam, Cornell Law Faculty Publications, 1975, p. 629, 630.

${ }^{11}$ An understanding of another legal system can be acquired only through contact and hence, familiarity with that system and its values. Absent this contact, the forum will examine unfamiliar laws as a foreigner, interpreting a foreign law in light of its own values. An objective examination and evaluation of the laws of another system, prescribed in the application of foreign law, requires some degree of empathy for the values peculiar to that system. Otherwise, the treatment of foreign law cannot be commensurate with that of domestic law. Because legal systems have little familiarity with other systems and their values, the forum's view of foreign law may be colored by the values of the forum community. Alexander Gregory S., op. cit., 1975, p. 636, 637.

12 International Encyclopedia of Comparative Law, volume 3, Private International Law, Kurt Lipstein Chief Editor, chapter 14, The application of foreign law Imre Zajtay, 1972, p. 30.
} 
This issue assume a considerable importance in certain civil law systems in which a higher courts, unlike the court in which the matter was first heard, does not determine the dispute, but controls only the decision under review, and controls it only in respect of question of law.

\section{Can the higher courts control the application of foreign law?}

In discussing this issue, first of all, we need to find out whether it is possible to review the decision on the basis of the application, non-application or wrong application of foreign law. The issue largely depends on the treatment of foreign law as a fact or a category of law.

Procedural law is essentially characterized by the distinction between questions of fact and questions of law. The effects of a classification as a question of fact or law distinction is important with regard to the judicial control of court decisions. The decision of a lower court may be overruled on appeal as far as questions of law are concerned, whereas the statements of fact made by the lower court normally are binding on the court of appeal. ${ }^{13}$ In most countries it is more difficult to appeal on a point of fact than on a point of law. In the case of the higher court, appeals on a point of fact may be impossible. The distinction between fact and law is, therefore, important for the purpose of determining whether a right of appeal exists. ${ }^{14}$ However, a country that treats foreign law as law will not necessarily allow appeals on points of foreign law to the higher court. On the other hand, there is at least one country in the foreign-law-as-fact camp where foreign law is treated almost the same as forum law for the purpose of appeals. ${ }^{15}$ It is important to make a brief survey of how this issue is regulated in a different legal system.

\subsection{Common law approach}

In some countries, higher courts have the power to control the correct application of foreign law by judges, and in some cases, the higher court lacks this ability.

Questions of foreign law were questions of fact at common law and continue to be so in some states. Important consequences flow from this categorization: the "fact" of foreign law must be pleaded; in proving the fact of foreign law, exclusionary evidence rules will apply; deference to lower court findings of fact will shield foreign law issues from de novo review by reviewing courts. ${ }^{16}$ Appellate courts, by virtue of their scope of review, invariably scrutinize a lower court's factual findings less closely than trial court decisions on questions of law. ${ }^{17}$ Classification

\footnotetext{
${ }^{13}$ Hausmann Rainer, Pleading and Proof of Foreign Law - a Comparative Analysis, 2008, p. 2.

${ }^{14}$ Trevor C. Hartley, Pleading and Proof of Foreign Law: The Major European Systems Compared, The International and Comparative Law Quarterly, Vol. 45, No. 2, 1996, p. 272.

${ }^{15}$ Ibid.

${ }^{16}$ Thomas F. Bridgman, Proof of Foreign Law and Facts, 45 Journal of Air Law \& Commerce, Volume 45, Issue 4, 1980, p. 845. https://scholar.smu.edu/jalc/vol45/iss4/4846 (accessed March. 25, 2021). ${ }^{17}$ Ibid.
} 
of foreign law issues as fact questions thus creates a presumption in favor of the lower court's rulings when based on conflicting evidence, even if the reviewing court might have decided the issue differently. ${ }^{18}$

In this system the distinction between questions of fact and questions of law determines whether a final appeal can be lodged to quash or to review the judgment below. ${ }^{19}$ In common law systems appeals are not limited to motions to quash or to modify judgments of lower courts on points of law only. ${ }^{20}$

The correct application of foreign law, as proven by evidence, is subject to verification by the superior courts of England. An appellate court will usually refrain from criticizing first instance findings as to the contents of applicable foreign law, but will normally be prepared to review the reasoning employed at first instance in order to reach a conclusion as to the effect of the foreign law in the case at hand. ${ }^{21}$ Where a trial judge makes a choice between conflicting representations as to the content of applicable foreign law, the appeal court may make a different choice if it considers that the judge's decision went against the weight of the evidence presented. ${ }^{22}$ The appellate court is not bound by the findings of the trial court on conflicting questions of foreign law. ${ }^{23}$

There are two, extremely broad and vague grounds upon which an appellate court in England is able to allow an appeal against a judgment handed down or an order made by an inferior court; that the judgment or order was "wrong" and that the judgment or order was "unjust because of a serious procedural or other irregularity in the proceedings in the lower court". ${ }^{24}$

\subsection{Civil law approach}

The majority of civil law countries, which provide for the mandatory application of foreign law, nowadays accept that errors in applying foreign law can be reviewed by higher courts including the Supreme Court, subject to the usual limitations on appeals. ${ }^{25}$

Foreign law is considered "law" in almost all civil law jurisdictions. The characterization of foreign law as "law" would equate foreign law with domestic law

${ }^{18} \mathrm{Ibid}$.

${ }^{19}$ International Encyclopedia of Comparative Law, op. cit., p. 31.

${ }^{20}$ Ibid, p. 30.

${ }^{21}$ International Encyclopedia of Comparative Law, op. cit., p. 30.

${ }^{22}$ The Application of Foreign Law in Civil Matters in the EU Member States and its Perspectives for the Future, Part I, Legal Analysis, Swiss Institute of Comparative Law, Lausanne 2011, p. 506.

23 One American author has stated: Doubtless in some jurisdictions appellate courts have a "propensity... to apply their own logic and reasoning in arriving at the law, rather than limiting these processes to examination of the trial court's conclusion. William B. Stern, Foreign Law in the Courts: Judicial Notice and Proof, California Law Review, Vol. 45, 1957, p. 28.

${ }^{24}$ The Application of Foreign Law in Civil Matters in the EU Member States and its Perspectives for the Future, 2011, p. 539.

25 Yuko Nishitani (ed.), Treatment of Foreign Law-Dynamics towards Convergence? Ius Comparatum-Global studies in Comparative Law, volume 26, Springer International Publishing, 2017, p. 37. 
and presuppose the mandatory application of foreign law by the judge. Even when foreign law is classified as "law", some countries deny or restrict appeals regarding its interpretation and application to the highest court, unlike in the case of domestic law. This is so in France, Germany and the Netherlands. ${ }^{26}$ In Belgium foreign law has been confirmed as legal since the Supreme Court sanctioned the review of lower courts' errors in applying foreign law. ${ }^{27}$

According to Austrian law, incorrect application of the Austrian Act on PIL constitutes a reason for nullity of the decision rendered, namely for the reason of "incorrect legal evaluation". ${ }^{28}$ Also the incorrect evaluation that the ascertainment of foreign law would take too much time is revisable under the same heading (incorrect legal evaluation). The same is true for incorrect application of the foreign PIL or foreign substantive law. If the Austrian courts did not have correct regard to the relevant, stable foreign practice or literature, this would also constitute a reason for a revision. ${ }^{29}$

In France, the interpretation and application of foreign law are not generally subject to review by the Supreme Court. Exceptions are only admitted in the following two cases: where the Court of Appeal has distorted the foreign law, i.e., committed a gross misinterpretation of foreign law, or where the Court of Appeal has failed to state sufficient grounds on the application and interpretation of foreign law to justify its decision and did not fulfill formal requirements. ${ }^{30}$ Where the appeal concerns an erroneous application of German procedural rules on the ascertainment of foreign law, the highest courts review the lower courts' decision for violating the duty to duly scrutinize foreign law ( $\$ 293 \mathrm{ZPO}) .{ }^{31}$

\subsection{Georgian law approach}

Georgian private international law and generally Georgian law is related to Roman-European law. Article 1 of Georgian PIL act defines the legal system to be applied and is comprised of positive law, natural law, customary law (written or not), mandatory and optional law, substantive and procedural law, private and public law. ${ }^{32}$ This article has the following wording: this law defines which legal system is to be applied with regard to the facts of a case where is a connection with a law of a foreign country, as well as to the norms of procedural law, to be applied during the proceedings of such a case. ${ }^{33}$ The facts of a case imply a definite composition of circumstances, one of the features of which (e.g. the place of signing a contract, a

26 Ibid.

${ }^{27}$ Ibid, p. 18.

28 The Application of Foreign Law in Civil Matters in the EU Member States and its Perspectives for the Future, p. 56.

29 Ibid

${ }^{30}$ Yuko Nishitani (ed.), op. cit., 2017, p. 37, 38.

${ }^{31}$ Ibid, p. 38.

${ }^{32}$ Sulchan Gamkrelidze, The Law of Georgia on Private International Law - Principles and Review, Georgian Law Review, Second and Third Quarter, Tbilisi: 1998, p. 23.

${ }^{33}$ Law of Georgia on Private International Law, 19-20, 29/04/1998, English version available at https://matsne.gov.ge/en/document/ download/93712/3/en/pdf. 
person's citizenship, the place of the fulfillment of the obligation etc.) shall have a relation to the law of a foreign country. Only after this a particular case can be considered with respect to private international law. ${ }^{34}$

Under Georgian private international law act foreign law rule is a question of law, so it is determined by the court ex officio. The court shall take the necessary measures to determine the essence of the foreign law, although the parties shall not be relieved of the burden of proving the content of a rule of a foreign State, and when for some reason its essence cannot be established, they shall cooperate with the court. The attitude of Georgian law, in which the balance between two different goals and interests is maintained by the cooperation of the court and the parties, reflects the achievements of European private international law.

According to Georgian civil procedure legislation the reason for reversing the judgment of a lower court by a higher court is the wrong application of substantive law or violation substantive law rules. The rules of substantive law are considered violated, if the court has not applied the law that it should have applied; has applied the law that it should not have applied; has interpreted the law incorrectly. Naturally, the question arises as to how the higher instance can control, for example, whether a foreign law that was applicable under private international law rules has been applied in a particular case, or whether a judge has applied a foreign norm that should not have been applied. Such control may be carried out only if the judges of higher court are familiar with foreign law.

Georgian private international law act does not contain a direct reference to whether a violation of foreign law or wrong application of foreign rules can become a ground for appeal or reversing a judgment, although it is entirely possible to reach this conclusion. ${ }^{35}$

For Georgian court foreign law is a matter of law and because, the court is obliged to determine the content of foreign law rules taking into consideration their official interpretation, application practice and doctrine in the respective country, consequently, wrong application of foreign law rules is a ground for revising or modifying a judgment. The question of whether it is permissible to appeal a court judgment in a higher instance in Georgia on the grounds of non-application or wrong application of foreign law, should be stated that there are no obstacles to this in accordance with Article 393 of the Civil Procedure Code of Georgia. This article clarifies that a cassation appeal can be based only on the fact that the judgment was rendered in violation of the law. Therefore, as in other countries, the concept of "law" used in Article 393 of the Civil Procedure Code of Georgia should not be understood narrowly, only by the law of Georgia, but its meaning should be expanded even if the Georgian court applies foreign law. In case of a relevant violation, a cassation appeal should be initiated under this article. ${ }^{36}$ So Georgian higher courts can examine the interpretation of foreign substantive law, also a legal review may be based on misinterpretation of foreign law or non-apply foreign law.

\footnotetext{
${ }^{34}$ Sulchan Gamkrelidze, op. cit., 1998, p. 23.

${ }^{35} \mathrm{Ibid}$, p. 23.

${ }^{36}$ Ibid, p. 80.
} 


\section{Foreign law in Georgia's higher court practice ${ }^{37}$}

The application of foreign law raises problems of its own. The process of determining a foreign law raises practical difficulties, as a judge must apply not just foreign law acts, but also the case law and interpretation with which it is applied in another State. To ascertain the exact meaning of foreign substantive law, the lower courts are often obliged to institute investigations. When applying a foreign law, the court shall take necessary measures to determine the essence of the rules of the foreign law taking into consideration their official interpretation, application practice and doctrine in the respective country. All necessary measures involves inviting an expert to provide the court with comprehensive information on the content of foreign law, about formal or unofficial explanation of its use. If higher instance are prepared to review the content of foreign law rules given by the lower court, it might be forced to examine also the conclusions of the research on which the court below relied. In spite of the development of comparative jurisprudence and modern information technologies, none of the countries' judge can have a claim on exact knowing of relevant standards of the law of foreign countries. Consequently, the danger of making a mistake is more greater when it comes to interpreting and applying foreign law. Thus, it cannot be expected that the high court should be able to review interpretation of foreign law acts applied by the lower courts and to provide that this interpretation is relevant to that which the practice of the foreign country would adopt on the same question.

Lower court judgments, in cases to which foreign law is applicable, are normally subject to review by superior instances in the same way as other first instance judgments. ${ }^{38}$ When lower court findings are challenged from the point of

${ }^{37}$ In Georgia the common court system is composed of the courts of first instance, the courts of appeal and the Supreme Court of Georgia, giving rise to a mechanism of double-review of court judgments before the latter may gain final force. There are two Courts of Appeals in Georgia. While Kutaisi Court of Appeals hears cases from the courts of first instances of Western Georgia, Tbilisi Court of Appeals exercises jurisdiction on the Eastern part of Georgia. The Courts of Appeals may hear both factual and legal arguments over the dispute, provided that the new facts, brought by the parties, could not have been reasonably presented during the proceedings in the court of first instance. Decisions of the Courts of Appeals may be appealed to the Supreme Court of Georgia, which represents a court of cassation, the highest judicial authority in the system of common courts of Georgia and which, as set in the Georgian Constitution, supervises "in accordance with existing legal procedure [...] the enforcement of justice of every court of Georgia, and reconsiders cases determined by law in the court of first instance." According to Code of Civil Procedure of Georgia, unlike the Courts of Appeals, the Supreme Court scrutinizes the cases against admissibility criteria before commencing cassation proceedings. The Supreme Court exercises its jurisdiction if: 1) the present case is important for the development of law and for the establishment of uniform legal practice; 2) the decision of the appellate court differs from the practice previously established by the Supreme Court for the same category of cases; 3 ) the appellate proceedings were conducted in a grave procedural violation which could have affected the outcome of the dispute. Borroni Andrea (ed.), Doing Business in Georgia. A Comparative Guide to Investors, Tbilisi: Meridiani Publishing Ltd, 2015, p. 58, 59, 60.

38 The Application of Foreign Law in Civil Matters in the EU Member States and its Perspectives for the Future, Part I, Legal Analysis, Swiss Institute of Comparative Law, Lausanne 2011, p. 38. 
view of foreign law, a basic distinction is usually made between a failure to apply the law correctly designated by rules of private international law, on the one hand, and materially incorrect application of the applicable foreign law, on the other hand..$^{39}$

Unfortunately, Georgian PIL Act is rarely used in practice. ${ }^{40}$ Consequently, Georgian private international law act has not changed over the years and the doctrine in this direction is less developed. The parties and most of the judges, due to their ignorance of foreign law, try to avoid referring to the law of another country. However, refraining from applying the rules of private international law is not only the Georgian reality. Most post-Soviet countries face a similar problem. Their legal education system does not allow for broad interpretations of the choice of foreign rules and their application. ${ }^{41}$

A unique event in the history of young Georgian judiciary took place in 2010, when a Georgian judge made a legal assessment of an institution of absolutely unknown form and content. Despite the brevity of the Supreme Court's reasoning, several important aspects can be highlighted. ${ }^{42}$

Panama-based company (Polestar) started an arbitration dispute in London against the Georgian government and won the lawsuit in 1999. In 2008, the plaintiff requested to the Queen's Bench Court in London to enforce the arbitral award. The court confirmed the requested enforcement. ${ }^{43}$ In September 2009, Polestar applied to the Supreme Court of Georgia to enforce the judgment of British court. ${ }^{44}$

\footnotetext{
${ }^{39}$ Ibid.

${ }^{40}$ After declared independence, Republic of Georgia began to adopt a number of new normative acts in the field of private law. The private international law of Georgia was developed during the period of the restoration of Georgia's independence. Georgian Law on Private International Law is intended to demonstrate that Georgia's legal system in this area is moving towards one based upon that of European Private International Law and upon the current legislation of leading European countries. Before the adoption of the Law by the Parliament of Georgia, numerous meetings were held within the relevant committees. The law came into force on October 1, 1998, and it was noted that its proper application would contribute to Georgia's integration into the international legal community. The Georgian Law on Private International Law is based upon: German law: Introductory Law for the Civil Code (EGBGB) adopted in 1896 and revised in 1994; Swiss law: Federal Law on Private International Law (1987); Italian law: Law on Private International Law (1995). Sulchan Gamkrelidze, op. cit., 1998, p. 20, 25.

${ }^{41}$ Gabisonia Zviad, Georgian Private International Law, second revised edition with additions, Tbilisi: 2016, p. 15.

42 Tsertsvadze Giorgi, International Civil Litigation, Fundamentals of Georgian Civil Law in Tamar Zarandia (ed.), Georgian Judicial Practice, TSU, Tbilisi: 2018, p. 318.

${ }^{43}$ Article 44 - Grounds for refusing the recognition or enforcement of an award: an arbitration award, irrespective of the country in which it is rendered, shall be binding and, upon bringing a written motion in court, shall be enforced in accordance with the provisions of this article. Awards rendered in the territory of Georgia are subject to the provisions of this article the competent courts shall be courts of appeal. In the case of awards rendered outside Georgia, the competent court shall be the Supreme Court of Georgia. Law of Georgia on Arbitration. 19/06/2009. English version available at https://matsne.gov.ge/ru/document/download/89284/5/en/pdf.

${ }^{44}$ It may also occur that parties to an arbitration request the confirmation of the award by the court of the place of arbitration, rather than seek for recognition and enforcement of it in another country. In this case, the issue of "double enforcement" of the arbitral awards arises. Double enforcement occurs
} 
The Supreme Court of Georgia has determined and interpreted the specific provisions of the 1996 English Arbitration Act for the purpose of full consideration and legal review of the 2008 judgment of the Commercial Court, which is a subdivision of the Queen's Bench Division. The Supreme Court discussed the wording and content of Article 66 of the Arbitration Law. ${ }^{45}$ However, court did not go into depth in the analysis of this article. Ideally, might be conducted a more indepth analysis of the relevant norms of English Arbitration Law and related practices, but given the limited resources available to conduct such investigations, it can be said that the court has successfully coped with the task of legal evaluation of a foreign court decision and has correctly established that the proposed judgment was more "domestic consumption act" of an English justice, than an internationally enforceable decision. ${ }^{46}$

The court relied on Article 66 of the English Arbitration Act and ruled that this decision was not enforceable in Georgia. So, Supreme Court refused to enforce a judgment of the English court that recognized and enforced the award against the Georgian Government in favor of Polestar. The Supreme Court pointed out that there was nothing enforceable in the English judgment because it constituted confirmation of the arbitral award for the sole purpose of simplifying its enforcement in England.

\section{Conclusions}

The circumstances are often not so typical for higher courts: in most cases, when disagreeing with appeals, judges are required to have knowledge of foreign law, although it is naturally, they may not even have such knowledge. However, the possibility of submitting new documents to a higher instance is substantially limited. In a number of cases where a lower court decides not to apply foreign law contrary to the rules of private international law, the higher court may assess the legality of such a decision. There are examples in court practice when a higher court seeks to apply foreign law, while first instances avoid its application. In fact, the power of the higher court to act as a controller, when the appealed decision is based on the rules of foreign law, is quite limited.

when courts are requested to recognize decisions deriving from other countries, which have recognized the arbitral awards. Parties resort to such choice in order to ensure those legal effects that are for their exclusive benefit. Nevertheless, the NYC has abolished the double enforcement procedure. Borroni Andrea (Ed.), op. cit., 2015, p. 183, 184.

45 Section 66 Enforcement of the award: (1) An award made by the tribunal pursuant to an arbitration agreement may, by leave of the court, be enforced in the same manner as a judgment or order of the court to the same effect. (2) Where leave is so given, judgment may be entered in terms of the award. (3) Leave to enforce an award shall not be given where, or to the extent that, the person against whom it is sought to be enforced shows that the tribunal lacked substantive jurisdiction to make the award. The right to raise such an objection may have been lost. (4) Nothing in this section affects the recognition or enforcement of an award under any other enactment or rule of law, in particular under Part II of the Arbitration Act 1950 (enforcement of awards under Geneva Convention) or the provisions of Part III of this Act relating to the recognition and enforcement of awards under the New York Convention or by an action on the award. Arbitration Act of England, 17 ${ }^{\text {th }}$ June 1996.

46 Supreme Court Decision of Georgia \#A 1985-S-68-09 Polestar, 26 March 2010. Tsertsvadze Giorgi, op. cit., 2018, p. 326, 327. 
Court of first instance decides a case on its merits applying foreign law, while the higher court reviews legality and reasonableness of the decision. However, they have different abilities in the process of ascertaining the essence of foreign law norms. If the lower court is not limited in its methods of determining the content of foreign law and can refer to a diversity of sources for this purpose, higher courts usually have only case materials and official published information on the relevant foreign law.

It is interesting to find out whether the sources of the foreign law used by the court of first instance to make a decision, must be attached to the case file. Higher court's judge should not rely on foreign law unless the case file indicates where the lower court obtained the information about these rules. In this situation, it is possible to assume a kind of presumption that the higher instances may not have known the content of foreign rules and at the same time lacked the practical opportunity to determine the content of such rules independently. Naturally, such a presumption should not exempt the higher courts from both the right and the duty to try and determine the content of foreign rules. If such an attempt is made and the higher court independently ascertained the content of the foreign law rules, then the relevant sources must be attached to the case file. Otherwise, the rights of party involved in the case will be violated, because he/she may be "unfamiliar" with foreign law and may not be able to determine the content.

\section{Bibliography}

1. Alexander Gregory S., The Application and Avoidance of Foreign Law in the Law of Conflicts: Variations on a Theme of Alexander Nekam, Cornell Law Faculty Publications, 1975.

2. Borroni Andrea (ed), Doing Business in Georgia. A Comparative Guide to Investors, Tbilisi: Meridiani Publishing Ltd, 2015.

3. Bridgman F. Thomas, Proof of Foreign Law and Facts, 45 Journal of Air Law and Commerce 1980.

4. Gabisonia Zviad, Georgian Private International Law, second revised edition with additions, Tbilisi: 2016.

5. Gamkrelidze Sulchan, Introduction to Private International Law, Tbilisi: 2000.

6. Gamkrelidze Sulchan, The Law of Georgia on Private International Law-Principles and Review, Georgian Law Review, Second and Third Quarter, Tbilisi: 1998.

7. Hartley Trevor C., Pleading and Proof of Foreign Law: The Major European Systems Compared, The International and Comparative Law Quarterly, Vol. 45, No. 2, 1996.

8. Hausmann Rainer, Pleading and Proof of Foreign Law - a Comparative Analysis, The European Legal Forum (E) 1-2008.

9. Lipstein Kurt (ed), International Encyclopedia of Comparative Law, volume 3, Private International Law, chapter 14, Imre Zajtay, The application of foreign law, 1972.

10. Lehmann Matthias, From Conflict of Laws to Global Justice, Columbia University, 2011.

11. McComish James, Pleading and proving foreign law in Australia, Melbourne University Law Review, Volume 31 (2), 2007.

12. Mskhvilidze Tamar, Foreign Law and High Courts in Private International Law, EEU Collection of Scientific Papers, no.1, Tbilisi: 2019. 
13. Powell F. Lewis Jr., Scherk v. Alberto-Culver Co. Supreme Court Case Files Collection, Box 18. Powell Papers, Washington \& Lee University School of Law, Virginia, 1973.

14. Stern William B., Foreign Law in the Courts: Judicial Notice and Proof, California Law Review, Vol. 45, 1957.

15. Wilson J. Matthew, Demystifying the determination of foreign law in U.S. courts: opening the door to a greater global understanding, The wake forest law review, 2012.

16. Yuko Nishitani (ed), Treatment of Foreign Law-Dynamics towards Convergence? Ius Comparatum-Global studies in Comparative Law, volume 26, Springer International Publishing, 2017.

17. Tsertsvadze Giorgi, International Civil Litigation, Fundamentals of Georgian Civil Law in Tamar Zarandia (ed.), Georgian Judicial Practice, TSU, Tbilisi: 2018.

18. Hague Conference on Private International Law, Access to Foreign Law in Civil and Commercial Matters, European Commission, Brussels 17.04.2012.

19. The Application of Foreign Law in Civil Matters in the EU Member States and its Perspectives for the Future, Part I, Legal Analysis, Swiss Institute of Comparative Law, Lausanne: 2011. 